\title{
Glimpse of Clinical Aerobiology in India: An Overview
}

\section{A B Singh* \\ CSIR-Institute of Genomics and Integrative Biology, Delhi University Campus, India}

Submission: December 12, 2017; Published: December 22, 2017

*Corresponding author: A B Singh, Emeritus Scientist (EX), CSIR-Institute of Genomics and Integrative Biology, Delhi University Campus, India, Email: singha49@hotmail.com

Abstract

Today more than $30 \%$ of the world population is known to suffer from one or other allergic ailments such as bronchial asthma, allergic rhinitis and atopic dermatitis. Major causative agents are pollen grains fungal spores, dust mites, insect debris etc. Detailed information on the daily seasonal and annual variation of different agents in the atmosphere is prerequisite in proper diagnosis and treatment of allergic ailments. Aerobiological investigations have been carried out in different parts of country to ascertain aerial concentration and seasonality of pollen and fungal spores. An attempt has been to review the important pollen/fungal allergens prevalent in different parts of the country during the last twenty five years. The studies carried out under an All India Coordinated Project on "Aeroallergens and Human Health" have revealed the quantitative and qualitative prevalence of aerosols at are different centers.

Predominant airborne pollen identified are Poaceae, Holopletea, Asteraceae, Eucalyptus, Casuarina, Putranjiva, Cassia, Cocos, Pinus, Cedrus, Cheno/Amaranth, Argemone, Xanthium, Parthenium and others. Allergenically important pollen are Prosopis juliflora, Ricinus communis, Morus, Mallotus, Alnus, Ouercus, Cedrus, Argemone, Amaranthus, Chenopodium, Brassica, Cocos, Parthenium, Cassia and grasses. The prevalent fungal spores in both outdoor and indoor environments are Aspergilli / Penicilli, Cladosporium, Ascospores, Alternaria Dreschlera, Epicocum, Nigrospora, Candida ablicans and others. Important fungal allergens are different species of Aspergillus, Ganoderma, Mucor mucedo, Fusarium solani, Curvularia, Nigrospora, Scopulariopsis brevicaulis, Alternaria alternata and others.

Air carries large number of bioparticles (biopollutants) and chemical pollutants and these poses burden for the respiratory tract of humans. The bioparticles include pollen grains, fungal spores, insect debris, plant parts, animal danders, mites, etc. These materials of biological origin are known to be causative agents of respiratory disorders like asthma, allergic rhinitis and atopic dermatitis. Rapid industrialization and urbanization though has resulted in booming the economy of the country but it has also contributed significantly in enhancing the problems of patients suffering from respiratory disorders as the quality of air deteriorated due to addition of large number of pollutants. The incidence of respiratory allergy is increasing all over the world. This is evident by the epidemiological data available from different parts of the world. The prevalence of respiratory allergy has been reported be $15-30 \%$ across the globe [1-5].

Of the various agents, pollen grains and fungal spores are the major source of morbidity among sensitive individuals. Detailed information on their daily, seasonal and annual variation in the Air carries large number of bioparticles (biopollutants) and chemical pollutants and these poses burden for the respiratory tract of humans. The bioparticles include pollen grains, fungal spores, insect debris, plant parts, animal dander, mites, etc. These materials of biological origin are known to be causative agents of respiratory disorders like asthma, allergic rhinitis and atopic dermatitis. Rapid industrialization and urbanization though has resulted in booming the economy of the country but it has also contributed significantly in enhancing the problems of patients suffering from respiratory disorders as the quality of air deteriorated due to addition of large number of pollutants. The incidence of respiratory allergy is increasing all over the world. This is evident by the epidemiological data available from different parts of the world. The prevalence of respiratory allergy has been reported be $15-30 \%$ across the globe [1-5].

Preparation of National and Regional pollen calendars is of immense help to the clinicians for effective diagnosis and efficient treatment of patients. India is blessed with multilingual, multicultural and multi religious population of more than 1.2 billion (1/5th of the world population). It comprises one of the richest flora on earth. India is one of the countries where aerobiological studies were initiated as early as 19th century. Studies on various aspects of aerobiology has progressed rapidly especially during the last twenty five years. An attempt has been made in this paper to review important air borne pollen and fungal allergens prevalent in different parts of the country.

\section{Earlier Studies}

Pollen grains caught attention of scientists in 18th century when Koelreuter reported dissemination of pollen by wind. After fifty years, pollen was suspected to be a causative agent of "Sumer Catarrah" (hay fever) by John Botock [6]. Later on Charles Blackley [7] established that pollen grains play an important role in hay fever and allergy. Scheppegrell [8] from
USA laid emphasis on field exploration and aerial surveys to record "aeroallergens" from the atmosphere. Subsequent studies carried out by different workers throughout the world established pollen to be responsible for respiratory allergic disorders [9-15]. In India, Cunningham [16] from Calcutta was the pioneer to establish relationship between the airborne 
organisms and the so called "Zymotic diseases". There was a conspiracy of silence on aerobiological studies for about half a century when two important centers started aerobiological investigations at Jaipur and Delhi [17-21]. Aerobiological studies in Kolkatta were initiated again at Bose Institute by Chanda and his students who also prepared pollination calendars for Calcutta, Falta and Kalyani [22-25].

Around same time extensive aerobiological investigations were initiated at Bangalore by S. N. Agashe [26,27]. Since then many centers have come up in different parts of the country which include Gwalior, Jabalpur, Santiniketan, Manipur, Gulbarga, Trivandrum, Lucknow, Mumbai and Bhopal [28-36]. Exhaustive studies have been carried out at different centers on airborne pollen types and their relationship with respiratory allergic disorders in atopic patients. Fungal spores were first reported to be an important cause of sensitivity in 1726 [37]. Blackley [7] suggested that Chaetomium and Penicillium $s p$ are associated with "bronchial catarrh". Nearly half a century later in 1924, van Leumen reported Aspergillus, Mucor and Penicillium to be responsible for allergic reactions. Subsequently many scientists throughout the world carried out aerial surveys using different samplers to identify important fungal types and studied fungal sensitivity in hypersensitive individuals [3,38-42].

In India aero mycological studies were initiated in 1959 with the work of T Sreeramulu at Visahkhapatnam. The studies spread further in other parts and many centers came into existence. The center at Aurangabad was initiated by S.T. Tilak in 1966 and the Mysore center was started by A. Ramalingam in 1965. Aerobiological studies at Madras were initiated by B.P.R. Vittal in 1976. Shivpuri and his students initiated work on fungal allergy in Delhi and the work is being carried out extensively by Singh and his students [43-47]. An All India coordinated project on aerobiology sponsored by CSIR, New Delhi was coordinated by Nair and Joshi (1980-83) and many new centers spread over 20 states carried out qualitative analysis of air borne pollen/fungal spores. The work carried out in different centers was compiled in the form a book entitled "Air borne pollen, spores and other plant material of India-A survey." Two decades later an All India coordinated project on "Aeroallergens and Human Health" was sponsored by The Ministry of Environment and Forest" Govt. of India was under taken and successfully completed by AB Singh and his collaborators [3]. This provides upto date information seasonal and annual concentration of air borne pollen and spores of indoor and outdoor air of different eco geographical regions of India.

\section{Aeropalynological Studies}

Studies on airborne pollen in India have been extensively studied during the last quarter century and have shown the existence of a rich and ever-changing air spora. From Delhi, aerial surveys have been carried out from time to time by Singh and his students. Singh and Babu [48-50] carried out aerobiological investigations to study variations in the pollen types of Delhi.
Malik et al. [51] studied air borne pollen grains from different zones of Delhi at human height. Two main pollen season were recognized (i) Feb.-April and Sept.-Nov. The dominant pollen grains reported were of Poaceae Cheno/Amaranth, Ricinus communis, Morus cannabis. Parthenium and Artemisia. Dirunal and seasonal variations of dominant pollen grains present in the atmosphere of Delhi has been studied by Singh et al [13]. A continuous air survey using Rotorod sampler for seven years was carried out by Singh et al. [14] from Delhi. The dominant pollen grains identified were Morus, Cannabis, Poaceae, Cheno/ Amaranath, Prosopis, Artemisia and Eucalyptus. Significant variations in the annual pollen concentration during the seven year investigation period were recorded. Long term variations are important to study as they provide insight into the changing scenario in the vegetation due to biotic factors.

During investigations carried out under AICP on Aeroallergens and human Health, 43 pollen types were recorded. Holoptelea was the major contributor (22.2\%) followed by poaceae $(1.8 \%)$ [3]. Aerobiological studies in Modi Nagar were carried out by Gaur and Kasana [52]. From, Gorakhpur, Poaceae was shown to be dominant [53]. Air borne pollen types of Dehradun were different from those observed in plains as pollen from pinaceae dominated at foothills of Himalayas. At Agra aeropalynological studies have been carried out by Shalini and Chauhan [54]. From Solan (Himachal Pradesh) 22 pollen types were recorded for high attitudes. The major pollen contributors to the atmosphere in Himalayan region were of Poaceae. Asteracese, Cassia, Quercus, Pinus and Cedrus [3]. Aerial surveys at Bikaner (Rajasthan) showed 35 pollen types to be present in the atmosphere [55]. Poaceae $(26.7 \%)$ ranks first followed by Amaranth-Chenopod (11.50\%) and cyperaceae (10.30\%). Maximum concentration of pollen was in March and minimum was in June.

From Bombay three pollen seasons are reported; (i) March-mid May (ii) Sept.-Nov. and (iii) Dec.-Feb. [56]. Grasses, Parthenium, Chenopodium-Amaranthus and Cyperus are the major source of air borne pollen in Kolhapur [57]. Atmospheric surveys revealed the important air borne pollen types representing the rural area around Gaya [58]. The studies conducted at Gwalior showed pollen of Poaceae, Asteraceae, Apocynaceae, Rosaceae, Cicer, Malvaceae, Ricinus and Bougainvillea to be dominant in the atmosphere. November was the month with maximum pollen catch [30]. Variability in grass pollen grains in India has been reviewed by Chaturvedi et al. [59]. Poaceae pollen has been reported to be dominant from the atmosphere of Nagpur [60]. The highest percentage was reported from Aurangabad (80.64\%) followed by Bhavnagar $(70.26 \%)$ and Raipur $(66.73 \%)$ all in central India. Qualitative seasonal variations in the atmospheric pollen flora of Jabalpur have been studied by Oomachan et al [61]. Atmospheric surveys carried out at Pune revealed Parthenium pollen to be the highest contributor to the atmospheric pollen load with two peak seasons (i) Sept-Nov and (ii) Jan-April [3]. 
In Eastern India, Chanda and his students from Kolkatta and N.I. Singh from Imphal carried out extensive aerobiological surveys to assess the pollen types of West Bengal and Manipur. Grass pollen was reported to be dominant aeropollen in West Bengal [24]. In general three pollen seasons are recognized from West Bengal. These are (i) Aug (ii) March-July and (iii) [24]. The aeroflora of Eastern Himalayas has also been analysed and the dominant pollen types reported are Acer, Alnus nepalensis, Betula, Pinus [32,34]. Under AICP, 59 pollen types were identified from the atmosphere of West Bengal and May was the month with maximum pollen concentration. At Guhati, pollen of Poaceae, Cheno/Amaranth, Asteraceae, Putranjiva, Mangifera and Eucalyptus were found to be most prevalent [3]. Poceae, Cassia $s p$ and Ageratum $s p$ are the dominant pollen types prevalent in the atmosphere of greater Silchar, Assam almost throughout the year [62].

From Southern India, Agashe and his students have made tremendous contribution in the study of aerobiology. The major pollen types identified from the atmosphere of Bangalore are Parthenium hysterophorus, Casuarina equisetifolia, Cheno/ Amaranth, Cocos nucifera, Ricinus communis and grasses [26]. As a result of aerial surveys carried out for six years Parthenium (48\%) was found to be most important weed followed by Poaceae and Casuarina equisetifolia [27]. Seasonal periodicity of predominant pollen in Bangalore atmosphere has been studied. Casuarina equisetefolia, Parthenium hysterophorus and Holoptelea integrifolia were the major types present. The concentration of Parthenium was found to be less as compared to earlier studies and this was attributed to rapid industrialization of Bangalore city and effectiveness of different eradication programmes [63]. Incidence of air borne pollen at two different locations was studied at Gulbarga.

Two pollen seasons, viz. Aug-Nov. dominated by weeds and grasses and Feb.-April dominated by trees and shrubs were recognized [36]. From the atmosphere of Trivandrum pollen of Cocos nucifera and Peltophorum were found to contribute $55 \%$ to the total pollen flora. From Trivandrum and Chennai 15 and 38 pollen types were identified and Poaceae was the most abundant type from both places [3]. Grass pollen (32\%) has been reported to be dominant pollen type from Hyderabad followed by Casuarina, Ricinus, Holoptelea, Ailanthus and others [33], Satheesh et al. [64] reported pollen of poaceae to be most predominant followed by Casuarina equisetifolia and Prosopis, juliflora from Kodaikanal. From Visakhapatnam, site to site variations in air borne pollen were found to be related to the density of vegetation in different zones [35]. Aerobiological data is of immense help in the preparation of pollen calendar which are very useful for the clinicians in correlating the presence of pollen in the air with seasonal allergic symptoms. Pollen calendars have been prepared from different geographical regions of the world. From India also pollen/flowering calendars have been prepared for Sambalpur, Gulbarga, Imphal and Kodai Kanal $[34,36,64,65]$. Centre for Biotechnology (now known as CSIR - Institute of Genomics and Integrative Biology) has published a book on pollen calendar of 12 different states of India [66]. The book also includes pollen seasons for grasses, weeds and trees prevalent in India.

\section{Clinically Important Pollen Allergens}

Pollen is important cause of allergic disorders and they vary from place to place. It is therefore important for the clinician to select only those pollen antigens which are prevalent in the area where patient is residing. Based on clinico-immunological studies carried out at different regions in the world, important pollen allergens have been identified. From Northern India, Prosopis, julflora, Xanthium, Ageratum, Amaranthus spinosus, Ricinus communis and Holoptelea integrifolia are reported to be important allergens [43]. Studies carried out at Kanpur established Amaranthus, Chenopodim, Holoptelea and grasses to be important offending allergens [67]. Positive skin reactions in $16.9 \%$ of patient to Pinus roxburghii from the foot hills of Himalayas has been recorded by Singh et al [68]. At Chandigarh, out of 35 pollen antigens tested showed highest skin reactivity against Rumex accetosa, Ailantus excelsa (17.6\%) followed by Trewia nudiflora (9.7\%), Argemone mexicana (9.5\%) and Cedrus deodara $(9.3 \%)$. In Delhi $12.6 \%$ of the atopic patients had positive skin reactions to Amaranthus spinosus, $8.5 \%$ to Populus deltoids and $7.5 \%$ to Dodonea viscosa and Bhauhinia variegata [3].

From Central India, important pollen allergens identified are Argemone, Brassica, Cannabis, Asphodelus, Parthenium, Cassia, Azadirachta, Poaceae, Alnus and Betula. In a recent study Morus and Trewia nudiflora and Parthenium have been added to the list of allergens from central India. From Eastern India, allergenically significant pollen types based on clinical evaluation are Lantana, Cucurbita maxima, Cassia, fistula, Cocos nucifera and Calophyllum inophyllum. High sensitivity to Cocos, nucifera has been recorded by Karmakar et al. [69]. In Calcutta, $28.8 \%$ of the patients were found to be positive against Solanum, sysimbrifolium, $21.1 \%$ to Crotolaria junceae and $18.2 \%$ to Ricinus communis and Ipomea fistula [3]. From Sourthern India important pollen allergens reported are Salvadora, Ricinus, Albizia lebbeck and Artemisia scoparia [70,71]. Allergenicity to Parthenium pollen is reported in $3.4 \%$ and $12 \%$ patients suffering from allergic rhinitis and bronchial asthma respectively from Bangalore [72]. At Trivandrum, maximum skin reactivity was recorded against Mallatus phillipensis (12.1\%) followed by Prosopis juliflora $(6.3 \%)$.

A. Airborne Fungi: Fungi are ubiquitous in nature and cosmopolitan in distribution. There are more than 80,000 spp of fungi and these have evolved elaborate mechanisms for their dispersal. The spores produced forms a normal component of outdoor air and also of indoor environment such as store houses, hospitals, libraries, residential building etc. Due to their small size, spores remain suspended in the atmosphere for a long time. When inhaled by susceptible individuals they cause respiratory disorders. Aerobiological 
studies in India have progressed along three different lines. These include (i) study of airborne fungal spores in the atmosphere of different places, (ii) study of fungal spores present in indoor environments and (iii) study of mycoflora over crop fields.

B. Outdoor Fungal Flora: Aerobiological studies have been carried out in different cities and towns to monitor air borne fungal spores. Various techniques like gravity settling method (settle plates, gravity slides), impaction techniques (Rotorod sampler and aeroscope) and volumetric devices (Burkard trap, Anderson samplers) have been popularly used. Cladosporium has been reported as the most predominant fungi by most of the investigators. Basidiospores and ascospores are the second dominant group. From Northern India, Aspergilli-Penicilli Cladosporium, Helminthosporium, Epicoccum and Drechslera are reported to be important fungi in ambient air. Singh et al. [68] carried out aerial surveys at Dehradun for two consecutive years. Cladosporium, Alternaria, smut spores, Curvularia, Ascospores, Nigrospora, Asp-Penicilli, Epicoccum were the dominant forms reported. July to October was the period of high spore catch. Gupta et al. [47] reported 98 fungal types from the atmosphere of Delhi as a result of two years of aerobiological survey at five different locations in Delhi metropolis. Cladosporium contributed $25-40 \%$ to the total air borne fungal load followed by Ustilago (24\%), A flavus (10-13\%) Alternaria (11\%) and A. niger (8\%). Aeromycological studies at Jabalpur have been carried out and important fungi prevalent in the atmosphere have been identified [73]. From Solan, 17 fungal types and from Lucknow 40 fungal types were recorded. The dominant types were Aspergilli-Penicilli, Cladosporium, Helminthosporium, Epicoccum and Drechslera [3].

Aerobiological surveys carried out in Eastern India revealed Aspergilli Penicilli, Cladosporium. Ascospores, rust and smut spores, Nigrospora, Periconia, Ganoderma and Rhizopus to be major fungal types. Sinha et al. [74] carried out aerial survey for aerofungi at Jameshedpur and reported 23 fungal genera with 40 species. Members of Deuteromycetes (14 genera) were dominant followed by Phycomycetes (5) and Ascomycetes (4). The important fungal types present in the atmosphere of Imphal, Manipur has been identified by Singh \& Singh [75]. Aeromycoflora at the foot hills of Eastern Himalayas has been studied by Majumdar and Bhattacharya [76]. A total of 18 fungal spore types were identified and the predominant types were Alternaria, Aspergilli, Cercospora, Cladosporium, Curvularia, Dreschlera, Epicoccum, Fusarium etc. A. flavus, A fumigatus, A. niger, P. citrinum and M. haemilis are dominant fungi recorded from the atmosphere of greater silichar area in Assam [62].

From Western India Tilak et al. [77] reported Deuteromycetes to contribute $70 \%$ to the total fungal aerospora in the atmosphere of Aurangabad. The other common types recorded are Alternaria, Curvularia, Nigrospora, Aspergilli-
Penicilli, Dreschlera, Periconia, Pithomyces, Stachybotrys, Memnoniella, Torula etc. Tilak [78] reported spore type belonging to 37 ascomycetes genera to be common in air. He classified them into four types based on their diurnal periodicity. He also suggested that there exist a close relationship between rainfall and release of ascosposes. Recent survey reported 18 fungal types and 22 fungal types from the atmosphere of Aurangabad and Pune respectively Cladosporium, Aspergilli-Penecilli, Curvularia, Rhizopus and Helminthosporium were the common fungal types encountered.

From Southern India studies on seasonal periodicity of fungal spores in Bangalore, the Garden city of India was conducted. Maximum concentration of dry spores were reported in North east Monsoon where as ascospores and basidiospores were dominant during South West Monsoon [79]. Nigrospora has been reported to be dominant fungi from Madras renamed as Chennai now [80,81]. Of the 34 fungal types identified from Visakhapatnam, Aspergilli-Penicilli, Cladosporium Curvularia, Basidiosposes, Uredosposes were the dominant types from Chennai. Of the 50 fungal types were identified, Periconia, Curvularia and Ganoderma were the dominant types. Tetraploa was reported to be dominant along with other fungal types from Trivandrum [3]. Adhikari et al [82] carried out study of airborne fungal spore in rural agricultural areas of India for two consecutive years. The concentration of viable fungi varied from 72-1796 colonies forming unit per cubic meter of air in the first year and 1551256 (CFU/m3) in the second sampling year.

C. Indoor Fungal Flora: Human beings are exposed to both outdoor and indoor environment. Environment of the work place plays crucial role in the hypersensitive individuals with the symptoms increasing during working hours and reducing afterwards. However, in some cases symptoms prevail throughout the day. Children employed in various industries are also exposed to occupational allergens. Studies on mycoflora of indoor environment are relatively few in India when compared with outdoors. The occupational areas surveyed include hospitals, poultry farms, libraries, bakeries farm houses, domestic houses, grain stocks, leather store houses etc. Aspergillus, Penicillium, Cladosporium and some moniliaceous fungi are predominant in the air of most of the indoor environment surveyed. The fungal flora observed in various working and occupational environments in India are briefly described here.

D. Bakery: Different sections of a bakery in Delhi were surveyed and 74 fungal types belonging to 33 genera were isolated [51]. Aspergilli/Penicilli (69.2\%) were the dominant spore type in the packing section with a peak in October followed by smut spores (28.5\%) with peak in Feb-April. Aspergillus flavus was the dominant fungal type in both packaging and storage section. Allergenically significant fungal aerosols have been shown to be prevalent in a rural 
bakery of West Bengal [82].

E. Granary: Aspergillus $s p$ are the predominant fungi followed by Cladosporium. A. flavus had two distinct seasons from Sept.-Nov. and May-June. Cladosporium was prevalent during winter months. Other important contributors are Rhizopus, Curvularia, A versicolor, A. fumigatus, Epicoccum nigrum and Alternaria [83]. Fungal diversity present in the dust of grain storage godowns has been studied by Pugalmaran and Vittal [84].

F. Poultry: Different sections of poultry were surveyed and 130 fungal types were identified [85]. In hatchery section, Aspergilli-penicilli spores were dominant. In poultry shed area, Cladosporium, Candida albicans, A. flavus, A. niger, Scopulariopsis brevicaulis, P. nigricans, Alternaria sp are reported to be predominant fungi. An analysis of the aeromycospora of a poultry farm in Kerala has been done and important fungal types identified by Jothish \& Nair [86].

G. Sugar Industry: Cladosporium is reported to be present in high concentration (60\%) from Nov-March in both baggase storage and cane cutting sections of the industry. The high concentration of Cladosporium coincided with the crushing season in Sugar industry. A fumigatus, Epicoccum, Saccharomyces and smut spores are other major contributors [87].

H. Library: Lot of workhas been done on the aeromycoflora of libraries. High concentration of Cladosporium, Penicillium, Paeciliomyces and Aspergillus sp were reported to be dominant in Library environment. After agitation of books, concentration of A. niger, Penicillium sp. and Cladosporium was found to increase several fold $[51,88]$. Nadimuthu and Vittal [89] reported air borne fungi to be present in low concentration in air conditioned libraries when compared with conventionally ventilated libraries. Mycoflora of library dust in Jaglaon (Maharashtra) was studied with reference to deterioration of books. Deuteromycotina members were found to be very common and showed luxuriant growth in the dust from stored books [90].

I. Cattle Shed: Two sections of a large rural indoor cattle shed were surveyed. Altogether 35 fungal types were identified. A. niger, A. flavus, and Cladosporium cladosporioides were found to be dominant fungal types recorded [91].

J. Residential Houses: Cladosporium and Aspergilli were found to be predominant in the houses of allergy patients in Bangalore [92]. A total of 17 fungal antigens were tested on patients with respiratory allergy in Agra. Rizopus nigricans showed maximum (20-95\%) allergenicity followed by Fusarium solani (14.80\%) [93].

K. Fungal Allergens: Fungal allergy is a worldwide problem. Many fungal species are known to cause severe respiratory and cutaneous allergic diseases. Several investigators from different parts of India have identified potential fungal allergens of their area. Shivpuri and his colleagues initiated clinical studies in Delhi in 1970's and found nineteen fungal extracts to be of allergenic significance. He reported C. cerbarum, A. niger, A. fumigatus, also to be important fungal allergens [43]. Important fungal allergens causing sensitization in patients of nasobronchial allergy of hilly regions has been identified. Ganoderma lucidium has been reported to induce sensitization in hypersensitive patients. Skin test results with spore and whole body extracts of Ganoderma showed $28.48 \%$ and $17.44 \%$ of patients to be positive to respective extracts [94]. Gupta et al [47] observed through ELISA that high level of specific IgE against Fomes pectinatis in the sera of exposed population. Common environmental allergens responsible for respiratory allergy have been reviewed by Singh \& Kumar [95]. From Bangalore, Mucor mucedo, Fusarium solani, Curvularia, Nigrospora were found to be allergenically significant [71]. A flavus Heminthosporium, Neurospora, Candida and Cladosporium have been reported to be important allergenic fungi in A.P. (Acharya, 1980).

L. Occupational Fungal Allergens: Epidemiological surveys for respiratory diseases were carried out among agricultural industrial workers such as bakeries, poultry farms, granaries and sugar industry. About $40-59 \%$ of workers in different work environments suffered from one or more respiratory ailments. Aspergillus was found to be the major contributor. The sensitization pattern of workers in a bakery environment revealed high level of IgE and IgG antibodies to six species of Aspergillus Scopulariopsis brevicaulis spores could sensitize poultry workers and this was evident by significantly high levels of IgE antibodies in the workers [75]. The work done by various investigators with respect to fungal allergens in both outdoor and indoor environment, has been reviewed recently by Singh and Deval [96]. Clinical studies were carried out at different places under AICP on "Aeroallergens and Human Health". The study provided important information on potential fungal allergens of different places. The important fungal allergens identified were A. ochraceous, A. japonicus, Cladosporium, Alternaria alternata, A. versicolor, Uromyces and Ustilago, A. ochraceous, A. Japonicus, Urmoyces, Ustilago, Neurospora sitophils, Sporotrichum has been reported to be allergenic for the first time [3].

M. Fungi of Crop Fields: Aerobiological studies with respect to plant diseases of different crops have been carried out by various investigators. Tilak \& Babu [97] investigated certain diseases of bajra crop. Aerial dissemination of uredinospore of ground nut rust was studied by Mallarah \& Rao [98]. Aerobiological and epidemiological studies with respect to ground nut rust have also been carried out by Murdhankar \& Pandey [99]. Aeromycoflora of crop fields like cereals, pulses, vegetables oil, seeds and cash crops have 
been conducted in Imphal. A close relationship between meterological factors, growth stage of crop and spore load in the air over the field was observed. In the maize crop, spores of pathogenic fungi were reported to be abundant in the air 4-5 weeks prior to the appearance of disease [100]. Alternaria alternata was reported to be causal organism of leaf and stem spot disease of sunflower. The conidia were trapped from the air when the crop was in flowering stage [101].

Day to day variations in the concentration of Alternaria over onion field infected with purple blotch was studied by Chawla \& Rajasaab [102]. The conidia were present in high concentration in the air when the crop was at 7-8 leaf stage state. Studies over a carrot field revealed that the concentration of conidia of Alternaria davuhi, the causative agent of leaf blight, increased with the progress of the disease [103]. The uredospores of Periodispora mori causing mulberry rust appeared in the air from August onwards and spore concentration gradually increased up to December corresponding with the disease severity [104].

Aerophyllo-mycoflora of some solanaceous crop plants in Bhilai Nagar (M.P.) showed fungal population to exhibit wide variation at different stages of crop development. Maximum number of micro-organisms were recorded during nascent stage and minimum number was observed during seedling stage [105] Aerial surveys over cotton field at Ahmedpur showed Ramularia areola, Cercospora sp. Helminthosporium sp, Alternaria $s p$ to be pathogenic to the cotton crop [106]. Hedge et al. [107] carried out studies at Ugarkhura and Dharwad (Karnataka) and reported load of uredospores of Phakopsora pacchyryhizi to be maximum in Aug-Sept. which also coincided with the critical stage of infection at flowering and pollination stages. They also developed prediction model for the disease based on severity of disease and environment factors. Ugarkhurd has been shown to be source of intection and hot spot for soyabean rust outbreak in Karnataka [108]. Many more investigators have made significant contributions to the knowledge towards aerobiology of fungal plant pathogens and have been reviewed recently by Vittal [109].

\section{Conclusion}

To conclude, the progress in the field of aerobiology has been very impressive in the last twenty five years. It was not possible to cover each and every paper published in this article but an attempt has been made to review selected publication from different geographical locations of India. However, with the understanding of molecular mechanism of allergy, both diagnosis and theerapy have gained prominent postion now.

\section{Future Priorities}

Allergy has been known for more than a century but the subject has suffered due to lack of knowledge on basic allergic mechanism and poor diagnostic procedures. In the last two decades a fast growth has been observed in the field of aerobiology. A large number of pollen/fungal allergens have been identified from different geographical locations. However due to urbanization and industrialization the flora of a region is continuously changing with respect to the number of weeds and introduction of exotic trees. Regular atmospheric surveys are therefore recommended in order to study the seasonal and annual variations of different allergens. Till date most of the surveys conducted are mainly in urban areas. Rural area should be included in the study as a major fraction of our population live in these areas. This is also important as maximum information on indigenous allergens is essential for the diagnosis and treatment of allergic disorders.

Aerobiological investigations should be correlated with clinical studies in order to establish a relationship between the concentration of allergens and the patient's syndrome. The increase in the prevalence of allergic diseases should be studied in detail. Efforts should be made to standardize the antigenic extracts prepared from various allergens. Another important aspect that is to be studied in detail is the cross reactivity among different allergens. This will be helpful in minimizing the suffering of patients to a great extent. The rapid development in the field of aerobiology has resulted in the understanding of prevalence of different allergens. This information should be linked with immunological and clinical studies so that it is of direct significance to both the patients and allergy practitioners.

\section{Fungal Prevention}

a. Identification of source and environmental conditions that help the fungi in getting airborne in significant concentrations should be known.

b. The substrate on which these microorganisms grow and flourish should be removed.

c. The kitchen should be kept clean and dry as it contains plenty of substrate for the growth of fungi.

d. Bathrooms should also be kept clean and dry.

e. As fungi are occupational hazards, the working environmental conditions should be improved.

f. Work places should be well ventilated and hygienic.

g. Reduction of moisture inside the work places is recommended.

h. The quality of air should also be improved by periodic maintenance of air treatment plant, fumigation and application of antifungal agents.

i. Personal filter masks of the pore size sufficient to stop the entry of respirable size microbes should be used.

j. Regular health check up of patients is recommended.

\section{Pollen Allergen Avoidance}

i. Allergen avoidance is the main strategy to control pollinosis.

ii. The common saying "prevention is better than cure" should be strictly observed in the case of allergy prevention. 


\section{Global Journal of Otolaryngology}

iii. The existing allergenically significant trees should be replaced by non-allergic trees in phased manner.

iv. Patients should avoid going outdoors on days of high pollen concentration in air.

v. Windows should be closed in the evening when pollen generally settles down to minimize their concentration in indoor environment.

vi. Use of air conditioners is recommended as it decreases indoor pollen count.

vii. Eliminate weed and grasses in and around your house.

viii. Don't plant too many trees or shrubs around your house.

ix. After coming home, take bath and wear fresh clothes.

x. A general awareness among people through media will also be helpful in controlling the problem of increasing respiratory allergy.

\section{References}

1. Pekkanen J, Remes ST, Husman T, Lindberg M, Kojasaari M, et al. (1997) Prevalence of asthma symptoms in video and written questionnaires among children in four regions of Finland. Eur Resp J 10(8): 17871794

2. Chhabra SK, Gupta CK, Chhabra P, Rajpal S (1998) Prevalence of bronchial asthma in school children in Delhi. J Asthma 35(3): 291-296.

3. Anonymous (2000) All India Co-ordinated Project on Aeroallergens and Human Health. Report. Ministry of Environment and Forests, New Delhi.

4. Anthracopoulos M, Karatza A, Lialios E, Triga M, Trianto K, et al. (2001) Prevalence of asthma among school children in Patras, Greece : three surveys over 20 years. Thorax 56(7): 569-571.

5. Woolcock AJ, Bastiampillai SA, Marks GB, Keena VA (2001) The burden of asthma in Australia. Med J 175(3): 141-145.

6. Bostock J (1819) Case of a periodical affection of the eyes and chest. Medico Chir Trans 10(1): 161-165.

7. Blackley CH (1873) Experimental researches on the cause and nature of catarrhus Aestivus. Dawson 1959. London p.57.

8. Scheppegrell W (1916) Hay fever in Southern states. $5^{\text {th }}$ Med J Nashivlle $9: 614$.

9. Solmon WR (1984) Aerobiology of pollinosis. J Allergy Clin Immunol 74(4): 449-461

10. Speiksma F, TM Assem, Avan Den, Collette BJA (1985) Air borne pollen concentration in Leiden, The Netherlands 1977-1981. II Poacea (grasses), variation and relation to hay fever 24(2): 99-108.

11. Galan C, Intante F, Infante N, De Clavijo, Guerra F, et al. (1989) Allergy to pollen grains from Amaranthacae and Chenopodiaceae in Cordoba, Spain Annual and daily variation of pollen concentration. Ann Allergy 63(5): 435-38.

12. Malik P, Singh AB, Babu CR, Gangal SV (1991) Atmospheric concentration of pollen grains at human height. Grana 30(1): 129-136.

13. Singh AB, Dahiya P, Gangal SV (1993) Volumetric survey of air borne pollen allergens in Delhi : Diurnal and seasonal variations. Ind J Aerobiol 10(6): 10-18.

14. Singh AB, Pandit T, Dahiya P (2003) Changes in air borne pollen concentration in Delhi, India. Grana 42(3): 168-172.
15. Holmquist L, Ekebom A, Kubler A, Vesterberg 0 (2005) Airborne birch and oak pollen grains and birch pollen allergens at a common sampling station in Stockholm. Grana 44(2): 104-107.

16. Cunningham DD (1873) Microscopic examination of air. Government press, Cacutta, India.

17. Kasliwal RM, Solomon SK (1958) Correlation to respiratory allergy cases with atmospheric pollen concentrations and meterologial factors. J Ass Physns. India 6: 180-195.

18. Kasliwal BM, Sethi JP, Soagi IC (1959) Studies in atmospheric pollen; daily census of pollen at Jaipur 1957-58. Ind J Med Res 47: 515-521.

19. Shivpuri DN, Vishwanathan R, Dua KL (1960) Studies in pollen allergy in Delhi area. Pollination calendar. Ind J Med Res 48: 15-20.

20. Dua KL, Shivpuri DN (1962) Atmospheric pollen studies in Delhi area in 1958-59. J Allergy 33: 507-512.

21. Shipuri DN (1964) Aeropalynology and its significance in allergy. In recent advances in palynology. pp. 420-438.

22. Chanda S (1973) Atmospheric pollen flora of Greater Calcuta and Facla Aspects Allergy Appl Immunol 6: 74-87.

23. Madras S, Chanda S (1979) Studies on the allergenic pollen of Kalyani, West Bengal. Botanical aspects. Aspects Allergy Appl Immunol 12: 101-106.

24. Chanda S, Mandal S (1980) Incidence of airborne pollen in Kalyani, West Bengal with reference to meterological parameters. Aspects Allergy Appl. Immunol 13: 1-13.

25. Mandal S, Chanda S (1980) Incidence of airborne pollen in Kalyani, West Bengal with reference to meterological parameters. Aspects Allergy Appl. Immunol 13: 1-13.

26. Agashe SN, Anand P, Manjunath K, Abraham JN (1983) Airborne pollen survey at Bangalore city (A preliminary study). Aspects Allergy Appl Immunol 16: 53-57.

27. Agashe SN, Alfadil AG (1989) Atmospheric biopollutants monitoring in relation to meterological parameters. Grana 28: 97-104.

28. Mittrte V, Khandelwal A (1973) Airborne pollen grains and fungal spores at Lucknow during 1969-70. Paleobotanist 22: 177-185.

29. Tripathi DM, Oomahan M, Rajrkar SK, Tiwari UC, Misra NP (1978) Studies on pollen allergy in Bhopal area-3 (Survey of atmospheric pollen). Asp Allergy Appl immunol 11: 232-239.

30. Jain AK, Mihsra R (1988) Airborne pollen grains, Fungal spores and other bio-components at Gwalior. Ind J Aerobiol 1: 30-40.

31. Ravindra PP, Joshi M, Sundaram P, Ghosh S, Gopi TBV, et al. (1988) Incidence of airborne pollen at Trivandrum during 1986-87. Ind J Aerobiol 1: 71-73.

32. Gupta S, Chanda S (1989) Aeropalynological survey in subtropical Eastern Himalayas, Kurscong Grana 28: 219.

33. Reddi KM, Ramaniyam CGK (1989) An aerobiological study of Hyderabad (A.P.). Asian J Pl Sci 1: 7-12.

34. Singh N, Devi KK (1992) Aerobiology and allergic human diseases in Manipur II. Airborne pollen grains of Imphal, Imphal District. Ind J Aerobiol 49-60.

35. Atluri JB, Narayan Rao KVV, Ramachandran M (1992) Site to site variation in airborne pollen grains at Visakhapatnam. Ind J Aerobiol Special Volume (Suppl): 29-38.

36. Bhat MM, Rajasab AJ (1992) Flowering calendar of potentially allergenic pollen producing plants of Gulbarga. Ind J Aerobiol (Special Vol.) 89-95.

37. Floyer J (1726) Violet asthma after visiting a wine cellar. A treat is asthma. $3^{\text {rd }}$ edn. London, UK. 


\section{Global Journal of Otolaryngology}

38. Aukrust L (1980) Allergens in Cladosporium herbarum. In advances in allergology and immunology (Ed. A. Oehling), Pergamon Press, Oxford.

39. Agarwal MK, Jonesh RT, Yunginger JW (1982) Shared allergenic and antigenic determinants in Alternaria and Stemphyllum extracts. J Allergy Clin Immunol 70: 437.

40. O Neil, Reed CR, Huges HA, Butcher BT (1987) Fusarium solani. Evidence for common antigenic/allergenic determinants with other fungi imperfecti. Clin Allergy 117-127.

41. Singh A, Prakash D, Singh AB (1998) Sensitization to different species of Aspergillus in bakery workers and general poupulation. Asian Pacifi J Allergy and Immunol 6: 5 .

42. Gupta SK, Pariera EMJ, Singh AB (1999) Ganoderma Lucidum; an aeroallergen in India. J Allergy Clin Immunol 17: 1.

43. Shivpuri DN (1980) Clinically important pollen, fungal and insect allergens for naso-bronchial allergy patients in India. Asp. Allergy Appl Immunol XIII: 19-23.

44. Singh BP, Singh AB, Nair PKK, Gangal SV (1987) Survey of air borne pollen and fungal spores at Dehradun, India. Ann Allergy 59: 229-234.

45. Singh A, Singh AB, Bhatnagar AK, Gangal SV (1990) Prevalence of Aspergilli in bakery environment. Ind J Aerobiol 3-15.

46. Singh A, Parkash D, Singh AB (1998) Sensitization to different species of Aspergillus in bakery workers and general population. Asian Pac J Allergy Immunol 16(1): 5-15

47. Gupta SK, Pereira BM, Singh AB (1999) Fomes pectinatis: an aeroallergen in India. Asian. Pac J Allergy Immunol 17(1): 1-7.

48. Singh AB, Babu CR (1980) Studies on pollen allergy in Delhi. Diurnal periodicity of common allergenic pollen 35(4): 311-317.

49. Singh AB, Babu CR (1980) Pollen types in the atmosphere of Delhi. Grana 19(1): 63-65.

50. Singh AB, Babu CR (1982) Survey of atmospheric pollen allergens in Delhi. Seasonal periodicity Ann Allergy 48(2): 115-122.

51. Maik P, Singh AB, Babu CR, Gangal SV (1990) Head high airborne pollen grains from different areas of Metropolitan Delhi Allergy 45(4): 298305.

52. Gaur RD, Kasana MS (1981) Studies on aerobiology of Modi Nagar. J Indian Bot Soc 60: 266-277.

53. Tripathi RN, Tripathi NN, Dixit SN (1986) Grass pollen content in the atmosphere of Gorakhpur. Mendel 3: 7-9.

54. Shalini S, Chauhan SVS (1999) Aeropalynological studies of Agra city. Ind J Aerobiol 12: 14-19.

55. Arora A, Jain VK (2001) Aeropalynological survey at Bikaner (Rajasthan). Ind J Aerobiol 14: 28-32.

56. Tripathi DM, Gupta SM, Vas CJ (1982) Aerobiological survey of Bombay. Part II (Pollen and spore calendar). Asp Allergy Appl Immunol 15: 4348.

57. Chaubal PD, Kotmire SY (1982) Aerobiological studies at Kolhapur Acta Botanica Indica 10: 100-120.

58. Sinha SS, Mishra KB (1988) Quantitative analysis of airborne pollen of rural area around Gaya Ind. J Aerobiol 1: 45-52.

59. Chaturvedi M, Datta K, Nair PKK (1992) Incidence of grass pollen in Indian Environment. Ind J Aerobiol 5: 20-24.

60. Kalkar SB, Patil GV (1994) Airborne biocomponents in the air of Nagpur. Ind J Aerobiol 7: 1-7.

61. Oomachan M, Mishra RP, Judha SD, Singh B (1996) Qualitative seasonal variations in the atmospheric pollen flora of Jabalpur. Ind J Aerobiol 9: $1-4$
62. Sharma D, Dutta BK, Singh AB (2004) Studies on seasonal and annual variations in atmospheric pollen and fungal spores of greater Silchar, Assam. Ind J Aerobiol 17: 1-11.

63. Agashe SN, Anuradha HG, Scinthia JDM (1999) Atmospheric pollen scenario in Bangalore during the past 15 years (1982-1997). Ind J Aerobiol 12: 30-32.

64. Satheesh R, Rao GR, PKK (1992) The airborne pollen incidence in relation to season and vegetation at Kodaikanal. Ind J Aerobiol p: 37-42

65. Pande S, Das AP, Chand S (1992) Flowering calendar of angiosperms in Sambalpur district, Orissa (India) Ind. J Aerobiol.

66. Singh BP, Singh AB, Gangal SV (1992) Pollen calendars of different states, India. CSIR center for Biochemical Pub, Delhi, India.

67. Gupta MC, Mittal OP, Katyar SK (1984) Pollen allergy in Kanpur. Aspects Allergy Appl Immunol 17: 99-105.

68. Singh BP, Singh AB, Prakash D (1987) Skin reactivity to airborne pollen and fungal allergens in patients of nasobronchial allergy of hilly region (India). In atmospheric Bio-pollution. Ed Chandra N pp: 125-134.

69. Karmakar PR, Das A, Chatterjee BP (1994) Placebo-controlled Immunotherapy with Cocos nucifera pollen extract. Int Arch Allergy Appl Immunol pp: 103-194.

70. Acharya PJ (1980) Skin test response to some inhalant allergens in patients of nasobronchial allergy from Andhra Pradesh. Aspects. Allergy Appl. Immunol 15: 49-52.

71. Agashe SN, Anand P (1982) Immediate type hypersensitivity to common pollen and molds in Bangalore city. Aspects Allergy Appl. Immunol 15: 49-52.

72. Subba Rao M, Prakash O, subba Rao PV (1985) Reaginic allergy to Parthenium pollen: evaluation by skin test and RAST. Clin Allergy 15: 449-454.

73. Verma KS, George AM (1997) Fungi of allergenic significance in the air of Jabalpur. Ind J Allergy Appl. Immunol 11(1): 13-15.

74. Sinha A, Singh MK, Kumbar R (1998) Aerofungi-an important atmospheric biopollulant at Jamshedpur. Ind J Aerobiol 11: 19-23.

75. Singh SR, Singh NI (1998) Fungal aerospora of Imphal. Ind J Allergy Appl Imunol 2(2): 37-42.

76. Majumdar MR, Battacharya K (2000) Aeromycoflora at the foot-hills of Eastern Himalayas. Ind J Aerobiol 13: 14-19.

77. Tilak ST (1980) Aeromycology at Aurangabad I. Ascospores Proc Ist Int Conf Aerobiol Munich pp: 145-147.

78. Tilak ST (1991) Aeromycology-Aspects and Prospects. In Fungi and Biotechnology: Recent advances Ed. HC Dube, Today and tomorrow's printers and publishers, New Delhi, India pp: 137-156.

79. Agashe SN, Sudha P (1990) Studies on seasonal periodicity of air borne fungal spores in Bangalore city. In Aerobiology Proc- $5^{\text {th }}$ Int Cont Ed SN Agashe, Oxford and 1BH pp: 31-38.

80. Vittal BPR, Krishnamoorthi K (1988) A census of airborne mold spores in the atmosphere of the city of Madras, India. Ann Allergy 60(2): 99101.

81. Gupta Bhattacharya S, Chanda S (2004) Sci Total Envion 29: 123.

82. Adhikari A, Sen MM, Gupta BS, Chanda S (2000) Incidence of allergenicaly significant fungal aerosol in a rural bakery of West Bengal, India. Mycopathologia Jan 149(1): 35-45.

83. Pandit T, Singh A, Singh AB (1995) Prevalence of culturable and nonculturable fungi in grain storage in Delhi. Aerobiologia 11: 177-182.

84. Pugalmaran M, Vittal BPR (1999) Fungal diversity in the indoor and outdoor environments and dust grain storage god owns. Ind J Aerobiol 12: $24-29$. 


\section{Global Journal of Otolaryngology}

85. Singh AB, Singh A (1996) Indoor Airborne fungi as important occupational sensitizers in poultry workers. Indoor Bult Environ 5(3): 138-147.

86. Jothish PS, Nayar TS (2003) An analysis of the aeromycospora of a poultry farm in Palakkad District, Kerala. Ind J Aerobiol 16: 17-22.

87. Pandit T, Singh AB (1992) Survey of air borne fungi in a sugar factory. Ind J Aerobiol.

88. Adhikar A, Sen MM, Gupta BS, Chanda (2004)

89. Nadimuthu N, Vittal BPR (1995) A volumetric survey of culturable molds in library environment. Ind J Aerobiol 8: 12-16.

90. Rane GM, Gandhe RV (2005) Air and dust Mycoflora of a library at Jalgaon. Ind J Aerobiol 18: 95-101.

91. Adhikari A, Sen MM, Gupta, BS and Chanda (2004)

92. Agashe SN (1994)

93. Chauhan SVS, Kulshrestha A, Goyal R (2004) Airborne fungi of Agra city with special reference to their allergenic significance. Ind J Aerobiol 17: 17-24.

94. Singh AB, Gupta SK, Pareira BMJ, Prakash D (1995) Sensitization to Ganoderma lucidum in patients with respiratory allergy in India. J Clin and Expt Allergy 25(5): 440-447.

95. Singh AB, Kumar P (2002) Common enviornmental allergens causing respiratory allergy in India. Ind J Pediatrics 69: 245-250.

96. Singh AB, Deval R (2005) Aerobiology of fungi associated with allergy. In Mold Allergy, Biology and Pathogenesis. VPKurup (eds) pp: 105-136.

97. Tilak ST, Babu M (1984) Aerobiology and epidemiology of certain diseases of bajra. Ind Bot 7: 77-83.

98. Mallaiah KV, Rao AS (1982) Aerial dissemination of urediniospores of ground nut rust. Trans Br Mycol Soc 78(1): 21-28.
99. Murdhankar SV, Pandey BN (1991) Aerobiological and epidemiological approach to ground nut rust. Ind J Aerobiol 4: 19-22.

100. Singh NI, Dorycanta H (1991) Aerobiology and crop diseases in Manipur. VIII Fungal air spora over a maize field in Senapati Distirct. Ind J Aerobiol pp: 141-144.

101. Ramachander Rao, KS (1993) Alternaria leat spot of sunflower I. Epidemiology and air borne conidia. Ind J Aerobiol 6: 45-48.

102. Chawla HT, Rajasab (1994) Day to day variations in the incidence of Alternaria porri conidia over a purple blotch infected onion field. In aerobiology Proc. $5^{\text {th }}$ Int Conf Ed SN Agashe Oxford 8 1BH pp: 221228.

103. Channabasavari J, Gudge, Redd N (1994) Aeromycoflora oven a carrot fields with special reference to airborne incolum of Alternari dauci In aerobiologia-Proc. $5^{\text {th }}$ Int Conference ed SN Agashe, Oxford \& IBH pp: 243-249.

104. Prasad KV, Dayakar Yadav BR, Sullia SB (1994) Aerobiology of Peridiospora mori causing mulberry rust. In Aerobiology Proc. $5^{\text {th }}$ Int Conference Ed SN Agashe. Oxford IBH pp: 261-272.

105. Sahu S (1998) Aerophyllo-Mycoflora of some solanaceous crop plants. Ind J Aerobiol 11 (1\&2): 27-32.

106. Jagannath S, Gaikwad B (1998) Aerobiological approach to aerolate mildew disease of cotton. Ind J Aerobiol 11 (1\&2): 33-37.

107. Hedge GM, Kulkarni, Srikant (2002) Aerobiology \& Disease prediction models of soyabean rust caused by Phakopsora pachyrhize. Ind Aerobiol 15: 1-14.

108. Hedge GM, Koycarnis S (2002) Probable (Phakopsora) path of soyabean rust. Ind J Aerobiol 5: 15-19.

109. Vittal BPR (2005) Progres of aerobiology in India during the last quarter century. An over view. Ind J Aerobiol 10: 60-68.

\section{Your next submission with Juniper Publishers will reach you the below assets}

- Quality Editorial service

- Swift Peer Review

- Reprints availability

- E-prints Service

- Manuscript Podcast for convenient understanding

- Global attainment for your research

- Manuscript accessibility in different formats ( Pdf, E-pub, Full Text, Audio)

- Unceasing customer service

Track the below URL for one-step submission https://juniperpublishers.com/online-submission.php 